Developments in East European Politics 
Also available from Macmillan Education

Patrick Dunleavy, Andrew Gamble, Ian Holliday and Gillian Peele (eds)

DEVELOPMENTS IN BRITISH POLITICS 4

Peter Hall, Jack Hayward and Howard Machin (eds) DEVELOPMENTS IN FRENCH POLITICS

Gillian Peele, Christopher Bailey and Bruce Cain (eds) DEVELOPMENTS IN AMERICAN POLITICS

Gordon Smith, William E. Paterson, Peter H. Merkl and Stephen Padgett (eds)

DEVELOPMENTS IN GERMAN POLITICS

Stephen White, Alex Pravda and Zvi Gitelman (eds)

DEVELOPMENTS IN SOVIET AND POST-SOVIET POLITICS

Forthcoming

Patrick Dunleavy

ANALYSING BRITISH POLITICS 


\title{
Developments in East European Politics
}

\author{
Edited by \\ Stephen White \\ Judy Batt \\ Paul G. Lewis
}


Selection and editorial matter (C) Stephen White, Judy Batt and Paul G. Lewis 1993

Individual chapters (in order) (C) Stephen White, George Schöpflin, David S. Mason, Gordon Wightman, Nigel Swain, John D. Bell, Jim Seroka, Krzysztof Jasiewicz, Jan Ake Dellenbrant, Ray Taras, Chris Corrin, Judy Batt, Bob Deacon, Daniel N. Nelson, Paul G. Lewis, Judy Dempsey 1993

All rights reserved. No reproduction, copy or transmission of this publication may be made without written permission.

No paragraph of this publication may be reproduced, copied or tranmitted save with writtem permission or in accordance with the provisions of the Copyright, Designs and Patents Act 1988, or under the terms of any licence permitting limited copying issued by the Copyright Licensing Agency, 90 Tottenham Court Road, London W1P 9HE.

Any person who does any unauthorised act in relation to this publication may be liable to criminal prosecution and civil claims for damages.

First published 1993 by THE MACMILLAN PRESS LTD

Houndmills, Basingstoke, Hampshire RG21 2XS and London Companies and representatives throughout the world

ISBN 978-0-333-59190-1 ISBN 978-1-349-22898-0 (eBook)

DOI 10.1007/978-1-349-22898-0

A catalogue record for this book is available from the British Library. 


\section{Contents}

Preface

ix

Notes on the Contributors

Map of Eastern Europe

xiv

Part One: Perspectives on Eastern Europe

1 Eastern Europe after Communism Stephen White 2

The Communist Inheritance 3

The Transition from Communist Rule 7

Eastern Europe after Communism 12

2 Culture and Identity in Post-Communist Europe George Schöpflin $\quad 16$

The Coming of Communism $\quad 20$

Post-Communism: Competing Political Cultures 24

Post-Communist Societies 28

Part Two: Models of Transition in Eastern Europe

3 Poland David S. Mason 36

The Erosion of Communist Rule 37

The Transition $\quad 40$

Issues in the Post-Communist Era 45

Economic 'shock therapy' 45

Political instability and the growth of populism 47

4 The Czech and Slovak Republics Gordon Wightman 51 The Transition 53

The June 1990 parliamentary elections $\quad 54$ 
Post-electoral discord

The June 1992 parliamentary elections

5 Hungary Nigel Swain 66

The End of the Communist Order 67

The Transition $\quad 70$

Political Issues in the Post-Communist System $\quad 74$

$\begin{array}{ll}\text { Creating a functioning pluralist political system } & 75\end{array}$

$\begin{array}{ll}\text { Creating post-communist conservatism } & 78\end{array}$

Transforming the economy $\quad 80$

6 Bulgaria John D. Bell 83

The End of the Zhivkov Regime 83

From Red to Blue $\quad 87$

The UDF in Power $\quad 92$

Economic reform $\quad 95$

Ethnic issues $\quad 96$

7 Yugoslavia and Its Successor States Jim Seroka 98

The Collapse of Tito's Socialist Experiment, 1981-1989 98

Collapse of the social contract 100

Failures in leadership and the collapse of regime legitimacy 103

Cessation of the security threat 104

Transition to Post-Communism and Current Challenges 105

Slovenia: western pluralism and parliamentary democracy 106

Croatia: pre-war political revival 109

Serbia and Montenegro $\quad 113$

Bosnia-Hercegovina $\quad 117$

$\begin{array}{lr}\text { Macedonia } & 119\end{array}$

Part Three: Patterns of Politics in Post-Communist EAstern Europe

8 Structures of Representation Krzysztof Jasiewicz 124

The Round Tables and the Umbrellas $\quad 124$

The Presidents and the Houses 134

The Seats and the Votes $\quad 140$ 
9 Parties and Party Systems in Eastern Europe

Jan Ake Dellenbrant

Types of Parties in Eastern Europe

Instability and Fragmentation in the Post-Communist

Party Systems

10 Leaderships and Executives Ray Taras 163

Nature of Executive Government 166

New Leaders in Eastern Europe 169

Albania $\quad 172$

Bulgaria 173

Czech Republic and Slovakia $\quad 175$

Hungary $\quad 177$

$\begin{array}{lr}\text { Poland } & 178\end{array}$

$\begin{array}{ll}\text { Romania } & 181\end{array}$

Political Leadership in Post-Communist Eastern Europe 182

11 People and Politics Chris Corrin 186

Political Changes in East-Central Europe 186

State/Societal Relations: Changes under Soviet Direction 188

Party politics 189

Consequences of changes since $1989 \quad 190$

Anti-politics 191

Civil society in power? 192

'New' Social Movements: Developments and Disintegration 194

Failure or success of social movements? 195

Women and Politics 196

Women's formal political participation 198

Changing women's situations 199

Women's activities towards change 201

Conclusion 203

12 The Politics of Economic Transition Judy Batt 205

The Communist System: Fusion of Economics and Politics 207

Reform within the Communist System: Politics and

Economics in Conflict $\quad 211$

From Economic Reform to Economic Transformation 214

13 Social Change, Social Problems and Social Policy Bob Deacon 225

From Nomenklatura Privilege to Market Inequality 226 
Social Policy and the Problems of Transition 229

Social justice and social policy 230

Citizenship and social policy 231

The Unique Issue of Post-Communist Social Policy 233

Recent Developments in Social Policy 235

International Agencies and East European Social Policy 238

Part Four: Eastern Europe and Political Science

14 The Comparative Politics of Eastern Europe

Daniel N. Nelson 242

The Birth and Death of Comparative Communism 242

The Promise and Failure of Comparative Communism 245

Towards a Comparative Politics of Eastern Europe 249

New Directions for Analysis and Research 253

The politics of transition 253

Democracy 255

Market 257

Security $\quad 259$

Conclusion $\quad 260$

15 History, Europe and the Politics of the East Paul G. Lewis 262

The End of History? 262

West of Centre? Post-Communist Europe between East and West

Intergration with the International Economy 271

States, Peoples and the Stability of Europe 274

16 East European Voices Judy Dempsey 280

The Voices $\quad 282$

Further Reading $\quad 289$

Bibliography $\quad 292$

Index $\quad 302$ 


\section{Preface}

It used to be easy to define 'Eastern Europe'. Broadly speaking, it was a group of states on the far side of what was for many years an Iron Curtain. Most of them bordered on the Soviet Union, and most of them were bound to the Soviet Union by economic and military alliances as well as by a close interconnection at the level of their communist party leaderships. Their fate, it appeared, had been largely determined at the end of the Second World War, when Europe had been divided - however provisionally - into rival spheres of influence. Yugoslavia had successfully separated itself from the Soviet alliance in the late 1940s, and from the 1960s Albania and Romania were increasingly independent. All of the states in the region none the less remained under communist leadership, state ownership was dominant, and public life was framed by the requirements of Marxism-Leninism.

The dramatic changes of the late 1980s and early 1990s have shattered these earlier patterns, and brought an end to the division of Europe and - in most parts of the region - to communist rule itself. The changes that began in 1989 took a variety of forms, and governments changed more quickly than political systems and forms of ownership, still less the habits and practices that had developed over forty years of communist rule - and in many cases over a much longer period. By the early 1990s, none the less, East European states were facing a largely similar set of challenges. Could they develop forms of rule, including party systems and structures of participation, that would replace the authoritarianism of the communist years? Could they find a balance between effective leadership, often through a presidency, and accountability, typically to an elected parliament? Could they reverse the economic decline of the late communist years, and could they best do so through 'shock therapy' or by a more gradual process? And could they carry out programmes of change with popular support, notwithstanding the sacrifices that were in- 
volved and the increasingly difficult position of students, the elderly, the handicapped, and a growing number of unemployed?

These are just some of the issues that are addressed in this collection, which brings together a number of leading specialists from the European countries and from North America. Our first two chapters set out the context of change, and explore some of the features that mark out a distinctively East European group of systems. We turn, in the second part, to a series of chapters that consider the process of transition in a number of individual states in the region: in Poland, the Czech and Slovak republics, Hungary, Bulgaria, and what has become known as the 'former Yugoslavia'. Our third part deals more comparatively with processes of change, including parties and parliaments, leaderships and the mass public, and the difficult transition from central planning to the market and a greater degree of social differentiation. Our fourth and final section examines the comparative politics of the region in a postcommunist era, and the place of Eastern Europe in a broader international environment; and we conclude with the voices of East Europeans themselves as they contemplate an uncertain future.

Developments in East European Politics is intended as a guide to the common patterns, as well as the individual variety, among a group of states that were formerly modelled on the Soviet Union but are now a distinctive and independent presence in a postcommunist international system. We hope that not only our students, but also our colleagues and readers in other walks of life, will find something of value in the result.

\section{Stephen White Judy Batt Paul G. Lewis}

Note: in the interests of reader-friendliness, accents and diacriticals have been omitted from Eastern European names. 


\section{Notes on the Contributors}

Judy Batt is Lecturer at the Centre for Russian and East European Studies, University of Birmingham, and is currently on secondment to the Foreign and Commonwealth Office, London. Her publications include Economic Reform and Political Change in Eastern Europe (1988) and East Central Europe from Reform to Transformation (1991).

John D. Bell is Professor of History at the University of Maryland in Baltimore and President of the Bulgarian Studies Association of North America. As well as numerous articles on modern Bulgarian history, he is the author of Peasants in Power (1977) and The Bulgarian Communist Party from Blagoev to Zhivkov (1986).

Chris Corrin is Lecturer in Politics at the University of Glasgow in Scotland. A specialist on East-Central European and women's issues, she is the author of Magyar Women: Hungarian Women's Lives 1960s-1990s (1993) and co-author of Superwomen and the Double Burden: Women's Experience of Change in Central and Eastern Europe and the Former Soviet Union (1992).

Bob Deacon is Reader in Social Policy at Leeds Metropolitan University in Leeds, England. His publications, as author or coauthor, include Social Policy, Social Justice and Citizenship in Eastern Europe (1992) and The New Eastern Europe: Social Policy, Past, Present and Future (1992).

Jan Ake Dellenbrant is Reader in Political Science at the University of Umea, Sweden. He has published books and articles on political and economic change in Russia/USSR, the Baltic States and Eastern Europe, including Gorbachev and Perestroika: Towards a New Socialism? (with Ronald J. Hill, 1990) and The New Democracies in Eastern Europe: Party Systems and Political Cleavages (with Sten Berglund, 1991).

Judy Dempsey works for the Financial Times. A graduate of Trinity College, Dublin, she is currently based in Germany and specialises in East-Central Europe. 
Krzysztof Jasiewicz is director of electoral studies at the Institute of Political Studies of the Polish Academy of Sciences, Warsaw, and is currently visiting professor of sociology at the Washington and Lee University in Lexington, Virginia. He was the co-author of a series of political attitude surveys known as The Poles of '80, '81, '84, '88 and '90, and has recently contributed to the Journal of Democracy and to the European Journal of Political Research, as well as to professional symposia.

Paul G. Lewis is Senior Lecturer in Government at the Open University, Milton Keynes, England. A specialist on Polish and comparative politics, his books include Poland: Politics, Economics and Society (with George Kolankiewicz, 1988), Political Authority and Party Secretaries in Poland 1975-1986 (1989), Democracy and Civil Society in Eastern Europe (edited, 1992) and Political and Economic Dimensions of Modernity (coedited, 1992).

David S. Mason is Professor of Political Science at Butler University, Indianapolis. A specialist in Polish politics and public opinion in East Central Europe, his books include Public Opinion and Political Change in Poland (1985) and Revolution in East-Central Europe (1992). He is currently coordinating a 12-nation survey project on popular perceptions of social, economic and political justice.

Daniel N. Nelson is Director of the Graduate Programs in International Studies at Old Dominion University in Norfolk, Virginia. During 1990-1 he was Senior Foreign and Defense Policy Advisor for the Majority Leader of the US House of Representatives, Richard Gephart, and he was previously a Senior Associate at the Carnegie Endowment and a Professor of Political Science at the University of Kentucky. His most recent books are Romania after Tyranny (1992) and Security after Hegemony (1993).

George Schöpflin is Lecturer in the Political Institutions of Eastern Europe at the London School of Economics and at the School of Slavonic and East European Studies. His recent publications include Politics in Eastern Europe 1945-1992 (1993).

Jim Seroka is Professor of Political Science and Public Administration at the University of North Florida in Jacksonville, Florida. He is the author of numerous scholarly articles and monographs on Yugoslav domestic and international politics, co-author of Political Organizations in Socialist Yugoslavia (1986) and coeditor of The Tragedy of Yugoslavia: The Failure of Democratic Transformation (1993). 
Nigel Swain is Deputy Director of the Centre for Central and Eastern European Studies at the University of Liverpool. His publications include Hungary: A Decade of Economic Reform (with Paul Hare and Hugo Radice, 1981), Collective Farms which Work? (1985), Hungary: The Rise and Fall of Feasible Socialism (1992) and Eastern Europe since 1945 (with Geoffrey Swain, 1993). He is currently researching the impact on rural society of the transition to private agriculture in Central Europe.

Ray Taras teaches politics at Tulane University in New Orleans. He studied at the universities of Montreal, Sussex and Essex, and at the University of Warsaw in Poland, and has taught at US universities since 1982. The author of Ideology in a Socialist State: Poland 1956-1983 (1983) and Poland: Socialist State, Rebellious Nation (1986), Ray Taras has also edited Leadership Change in Communist States (1990) and Handbook of Political Science Research on the USSR and Eastern Europe (1992).

Stephen White is Professor of Politics and a Member of the Institute of Russian and East European Studies at the University of Glasgow. A specialist on Soviet, Russian and comparative politics, his books include The Origins of Detente (1985), The Bolshevik Poster (1988), Communist Political Systems: An Introduction (3rd edn, 1990) and After Gorbachev (4th edn, 1993). He is presently working on a survey-based project on democratic values in Russia, Ukraine, Hungary and the former Czechoslovakia.

Gordon Wightman is Lecturer in the School of Politics and Communication Studies at the University of Liverpool. His articles on Czechoslovak politics have appeared in Electoral Studies, Parliamentary Affairs and the Journal of Communist Studies, and in professional symposia. He is presently engaged in an interuniversity research project on 'Regime change in East-Central Europe', sponsored by the UK Economic and Social Research Council under its East-West Initiative. 


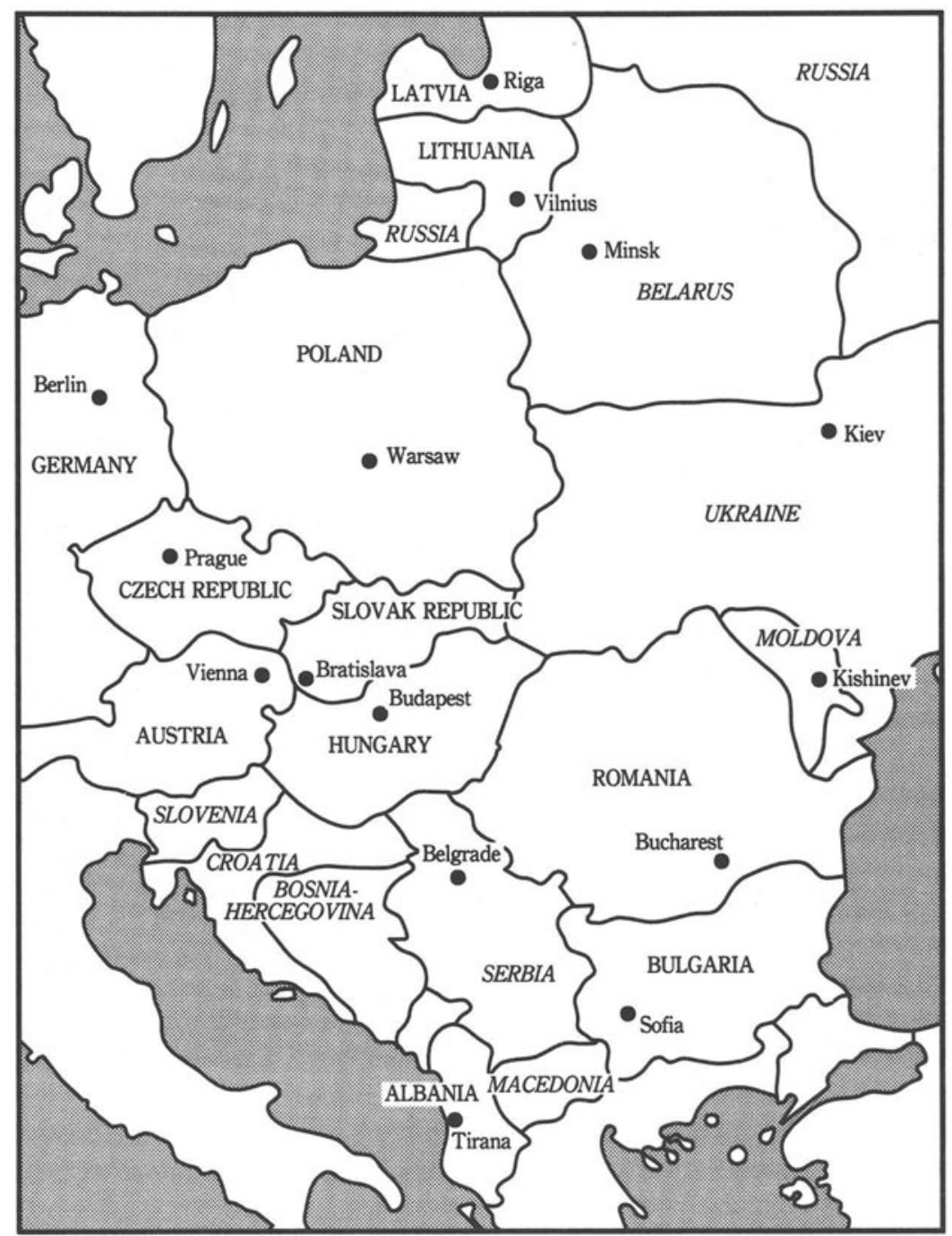

Map of Eastern Europe 